\title{
Analysis of Nile River Floods Based on Annual Natural Flows at Aswan, Egypt
}

\author{
Ahmed Helmy El-Sayed \\ Assoc. Prof., Water Eng. Dept., Faculty of Eng., Zagazig Univ., Zagazig, Egypt \\ Tel/Fax: 055-2316088, e-mail: Ahelmy12@hotmail.com
}

\begin{abstract}
The present paper discusses the aralysis of Nile River floods at Aswan, Egypt. A brief description of the Physiography, climate, and hydrology of the Nile Basin was outlined. The correlation together with the contribution of each of the four tributaries of the Nile River with the Main Nile at Aswan was investigated. The contribution of flow to the Main Nile at Aswan from Ethiopia was found about $86 \%$. The fluctuation of maximum and mirinum flows of the Main Nile at Aswan was studied by smoothing the annual flows at Aswan using moving average technique. The annual flows of the Nile River at Aswan showed a short-term fluctuation of average cycle of about 11 years and a long-term fluctuation every about 42 years. The flow series at Aswan was smoothed by double three-year moving average and then modeled by an ARMA model having moving average parameters at the obtained 11 , and 42 lags. The adequacy of the developed model was as well examined and approved in both the historical and the validation periods. The model was used to forecast future values of the annual flows at Aswan up to year 2022. A low flow year was expected about year 2008 while a high flood year was expected about year 2010 of a mean flow of about $90 \times 10^{9} \mathrm{~m}^{3}$, and 91 $\times 10^{9}$ in the coming 11 -years and 21-years respectively that give some feel of comfort about the future of the promising great agriculture development projects in Egypt.
\end{abstract}

Key words: Natural Flows - Nile River - Forecasting - ARMA Model - Moving Average.

\section{Introduction}

The Nile is the longest river in the world. From its remotest headstream in Burundi to its estuary in the Mediterranean Sea, it traverses a total distance of about $6700 \mathrm{~km}$ and over 35 degrees of latitude. It drains a basin area of about $3,350,000 \mathrm{~km}^{2}$ stretching over ten east-central and northeast African countries [3, 8]. About 99 percent of Egypt's and 80 percent of the Sudan's present water supply come from the Nile. The Sudan and Egypt need all the water they can get from the Nile and are highly dependent on the water claimed by other countries [5, 9]. Egypt derives its percent of current water supply from the Nile in the form of surface and subsurface flow.

The aim of the present research is to simulate and hence forecast the behavior of the Nile River floods based on its annual natural flows at Aswan. A brief description of the Physiography, climate, and hydrology of the Nile Basin is followed by an analysis of the contribution of the different tributaries of the Nile to the Main Nile at Aswan. Finally, a discussion of the applied methodology and the results of the developed model are presented.

\section{Physiography of the Nile River:}

The Nile River basin is immense and occupies an area about one-tenth of the continent of Africa. It includes portions of Tanżania, Burundi, Rwanda, Zaire, Kenya, Uganda, Ethiopia, Sudan, and Egypt. The Nile River basin (Fig. 1) has seven major region's [7]: Lake Plateau of East Africa, Al-Jabal, White Nile, Blue Nile, Atbara, Main Nile -north of Khartoum in the Sudan and Egypt, and Nile delta. 
The Nile River has a number of sources. The Lake Plateau region of East Africa has several headstreams that contribute to the White Nile. The Kagera River is considered the furthest headstream. It rises in the highlands near the northern edge of Lake Tanganyika and then flows into Lake Victoria. The Nile River then rises from Lake Victoria and flows northward near Jinja. The Victoria Nile continues its flow into Lake Kyoga, where it passes through its swamp vegetation and then it changes its flow and continues towards the west where it descends into the East African Rift System. From here it flows into Lake Albert, which is deep and narrow. It now becomes the Albert Nile and continues northward through a wider section of the river. This part of the river is navigable.

The Nile enters The Sudan at Nimule and becomes the Al-Jabal River. This portion of the Nile is not navigable due to the series of rapids that are formed while the river descends through narrow gorges. Once it reaches Juba it flows over large and level clay plain. The mainstream flows through its center and during the rainy season flooding will occur. This allows aquatic vegetation to grow in abundance. In the long run, as the water flows through this area, large amounts of vegetation are dislodged and carried downstream where they fill the channels and prevent navigation. The basin in this area also, receives drainage from other rivers and streams. Only a small amount of water is added to the Nile since some of the contributors lose tremendous amounts of water from evaporation [4].

The White Nile begins near Malakal, where the Sobat River joins the mainstream of the Nile. It continues for about $800 \mathrm{Km}$ with very little water being added from other sources along the way. This section of the Nile is wide and the water flows slowly alopg its course. Narrow swamps occur frequently along the edges. These conditions contribute to the huge amounts of water lost throligh evaporation and seepage.

The water of the Blue Nile drains from the Ethiopian Plateau, where it descends from 1,800 meter above sea level. It continues in a north-northwesterly direction through the Sudan till it joins the Main Nile at Khartoum. The White Nile has a relatively constant flow; the Blue Nile in contrast is affected by the great runoff resulting from the late July to October rains on the Ethiopian Plateau. The annual floods in Egypt are a direct result of this increase in the river's water volume.

The Atbara River flows into the Nile about $320 \mathrm{Km}$ north of Khartoum. The two tributaries Angered and Takes of the Atbara River bring tremendous amounts of water from the Ethiopian highlands between July and October and contribute to the flooding downstream.

The Main Nile north of Khartoum has two distinct parts. One part is about $1300 \mathrm{Km}$ long and flows through a desert region. Irrigation takes place along this stretch. The second part involves Lake Nasser where the Aswan High Dam holds the water back. Another stretch of the Nile flows northward below Khartoum. A series of cataracts occur leading towards Lake Nasser. For the $1200 \mathrm{Km}$ that the river, flows through this portion it changes from gentle sections to a series of rapids. It is the crystalline rocks that have caused five of the famous cataracts in the river making portions of it not navigable. Finally, the Nile delta was formed. It is composed of the silt carried by the river from the Ethiopian Plateau.

Climate and hydrology of the Nile Basin: The Nile basin has two types of climates. In the northern part, the part where the Sudan and Egypt lie has virtually no rainfall in the summer. In contrast the southern portion, which encompasses the Ethiopian Plateau, has heavy rains during the sunmer months. During the season between October and May both regions are relatively.. dry due to the presence of the northeast trade winds. 
East African lakes region and southwestern Ethiopia have more tropical climates. Rainfall occurs throughout these regions. However, the rainy season is considered to occur from April to October. Temperatures vary between 15 to 27 degrees C., with relative humidity averaging around 80 percent. The southernmost part of the Sudan has a similar climate, with as much as $1270 \mathrm{~mm}$ of rain during the rainy season. North of this tropical region there is a shorter rainy season occurring from July to August. There is less rainfall. In the central region of Sudan, the seasons start with a cool, dry winter (December to February). This changes in March to hot, dry weather with temperatures averaging 41 degrees $C$. Finally in July the rains come and the conditions are hot and rainy. Rainfall in this region varies from 250 to $530 \mathrm{~mm}$ annually. As one continues north of Khartoum the annual rainfall is $127 \mathrm{~mm}$ [8].

The remainirg area in the north is characterized as having a desert climate. This area includes northern Sudan and the Egyptian desert. It is considered to be arid and extremely hot. In June the average temperature is 47 degrees C. In Egypt's desert there is a winter season with cooler temperatures and rainfall varies from 25 $\mathrm{mm}$ in the south and increases up to 200 $\mathrm{mm}$ as it reaches the coastal area. In these desert areas sandstorms can occur during the spring months. These sandstorms can last for three or four days and end with a desert phenomenon known as a "blue sun".

\section{Contribution of Nile Tributaries to the Main Nile at Aswan:}

On the Nile River and its tributaries, there are a lot of gauging stations for recording its flows. Among these stations, there are twelve main stations that routinely record the daily change of the Nile flows since 1912. These stations includes Mongalla on Bahr El-Gable Basin, Malakal and Mogren on the White Nile, Sobat on River Sobat, Roseires; Sennar; and Khartoum on the Blue Nile, Atbara on mouth of River Atbara, and Tamaniat; Hassanab, Dongola, and Aswan on the Main Nile. A complete set of ten-day natural flows at these stations are calculated and aggregated to yearly flows as given by Talaat et al, 2002 [10].

In the present research, the natural annual flow records at five gauging stations are used for analysis. One of them is located at Aswan on the Main Nile while the other four stations are located at Khartoum on the Blue Nile, Atbara on the River Atbara Mouth, Sobat on River Sobat, and Malakal on the White Nile. For Aswan, the flow records start in 1871 and end in 2001. The annual flow records for the other four stations starts in 1912 and ends in 1992.

The correlation between the four tributaries of the Nile and the Main Nile is examined by the aid of the cross-correlation diagram (CCD). The significant observation that can be made from the plot of the CCD is the good correlation between Khartoum and Atbara with the Main Nile at Aswan as shown in Figs. 2, and 3. The high correlation between the flows at Khartoum and Aswan ( $r=0.784$ ) results from the fact that the flow of the Main Nile at Aswan is highly dependent on the flow of the Blue Nile. A non-significant correlation is found between both of Sobat and the White Nile with Aswan.

To find the contribution of the Blue Nile at Khartoum, Atbara River, the Sobat, and the White Nile at Malakal to the flow of the Main Nile at Aswan, the flows of the Main Nile at Aswan are plotted against the flows of the Blue Nile at Khartoum, River Atbara, White Nile at Khartoum, and White Nile at Malakal as shown in Figs. 4, 5, 6, and 7 respectively. Also shown in the figures are the regression lines and the $95 \%$ confidence intervals. The relation between the llows of the Nile tributaries and Aswan are expressed by Eqs. 1, 2, 3, and 4 as follows:

$\mathrm{Q}_{\mathrm{K}}=1271.26+0.57 \mathrm{Q}_{\mathrm{Asw}}$ 
$Q_{A}=-5815.43+0.20 Q_{A s w}$

$Q_{w}=6525.80+0.24 Q_{\text {Asw }}$

$Q_{M}=16541.68+0.15 Q_{A s W}$

In which, $\mathrm{Q}_{\mathrm{K}}=$ Natural flow of the Blue Nile at Khartoum in $\left(10^{6} \mathrm{~m}^{3}\right)$,

$\mathrm{Q}_{\mathrm{A}}=$ Natural flow of the River Atbara at Mouth in $\left(10^{6} \mathrm{~m}^{3}\right)$,

$Q_{w}=$ Natural flow of the White Nile at its Junction with the Main Nile at Khartoum in $\left(10^{6} \mathrm{~m}^{3}\right)$

$\mathrm{Q}_{\mathrm{M}}=$ Natural flow of the White Nile at Malakal in $\left(10^{6} \mathrm{~m}^{3}\right)$, and

$\mathbf{Q}_{\text {Asw }}=$ Natural flow of the Main Nile at Aswan in $\left(10^{6} \mathrm{~m}^{3}\right)$.

More than half the total surface area of the land of Ethiopia drains into the Blue Nile, and the rest drains to the Main Nile through the Atbara River and to the White Nile through the Sobat River. Based on the regression analysis for the annual flows, the contribution of the Blue Nile to the Main Nile is about $57 \%$ on the average (Eq. 1) and that of the Atbara River is about 20\% (Eq. 2). The contribution of the White Nile at its Junction with the Main Nile at Khartoum including the portion drained from the Sobat to the White Nile is about $24 \%$ (Eq. 3) while that of the White Nile at Malakal is about 15\% (Eq. 4). Eqs. 3 and 4, indicate that the contribution of the Sobat River is about $9 \%$. Summing the contributions of the Blue Nile, the Atbara River, and the Sobat River, gives the contribution of flow to the Nile from Ethiopia to about $86 \%$. From such an analysis, we find that the variability in the flow of the Main Nile at Aswan largely reflects the runoff from Ethiopia.

The Methodology:

The methodology that will be followed in the present paper depends on modeling and hence forecasting the smoothed annual flows instead of the original one. The forecasted values of the smoothed series are then redistributed to obtain the forecasts of the original series. The class of ARMA models advocated by Box, $1976[2]$ is used throughout this application.

Smoothing the Annual Flows at Aswan:

Evidence of long-term fluctuations and trends in the Nile flow data may be obtained by a study of progressive longterm averages using three-year, five-year, or seven-year moving averages (MA). Looking at the flow data in terms of moving averages has the advantages of filtering out short-term fluctuations and enables one to look at the long-term fluctuations and trends in the data. To develop these moving averages, the annual flow records of the Nile River at Aswan are examined. For a three-year MA, the flow data are averaged over successive threeyear periods. The first average would be obtained for years one, two, and three and plotted at year two. The second average would be obtained for years two, three, and four and plotted at year three, etc. A double 3 -year moving average is a 3-year MA of a 3-year MA. It is equivalent to a 5-period weighted moving average. Equations 5, 6 and 7 can compute the 3 -year, 7-year, and a double 3 -year moving averages as follows:

$$
\begin{aligned}
& Q_{3}=\left(Q_{i-1}+Q_{1}+Q_{i+1}\right) / 3 \\
& Q_{7}=\underset{\left(Q_{i-3}+Q_{i-2}+Q_{i-1}+Q_{i}+Q_{i+1}+Q_{i+2}+\right.}{\left.Q_{i+3)}\right) / 7}
\end{aligned}
$$

$Q_{D 3}=\left(Q_{i-2}+2 Q_{i-1}+3 Q_{i}+2 Q_{i+1}+Q_{i+2}\right) / 9$

In which,

$\mathrm{Q}_{3}=$ the three-year moving average,

$\hat{\mathrm{Q}}_{7}=$ the seven-year moving average,

$\mathrm{Q}_{\mathrm{D} 3}=$ the Double three-year moving average, and

$Q_{i} \quad{ }^{\prime}=$ annual flow for the year $i$.

Figure 8 shows the plot of the seven-year moving average flows of the Main Nile at Aswan in which short-term fluctuations are filtered and the evidence of 


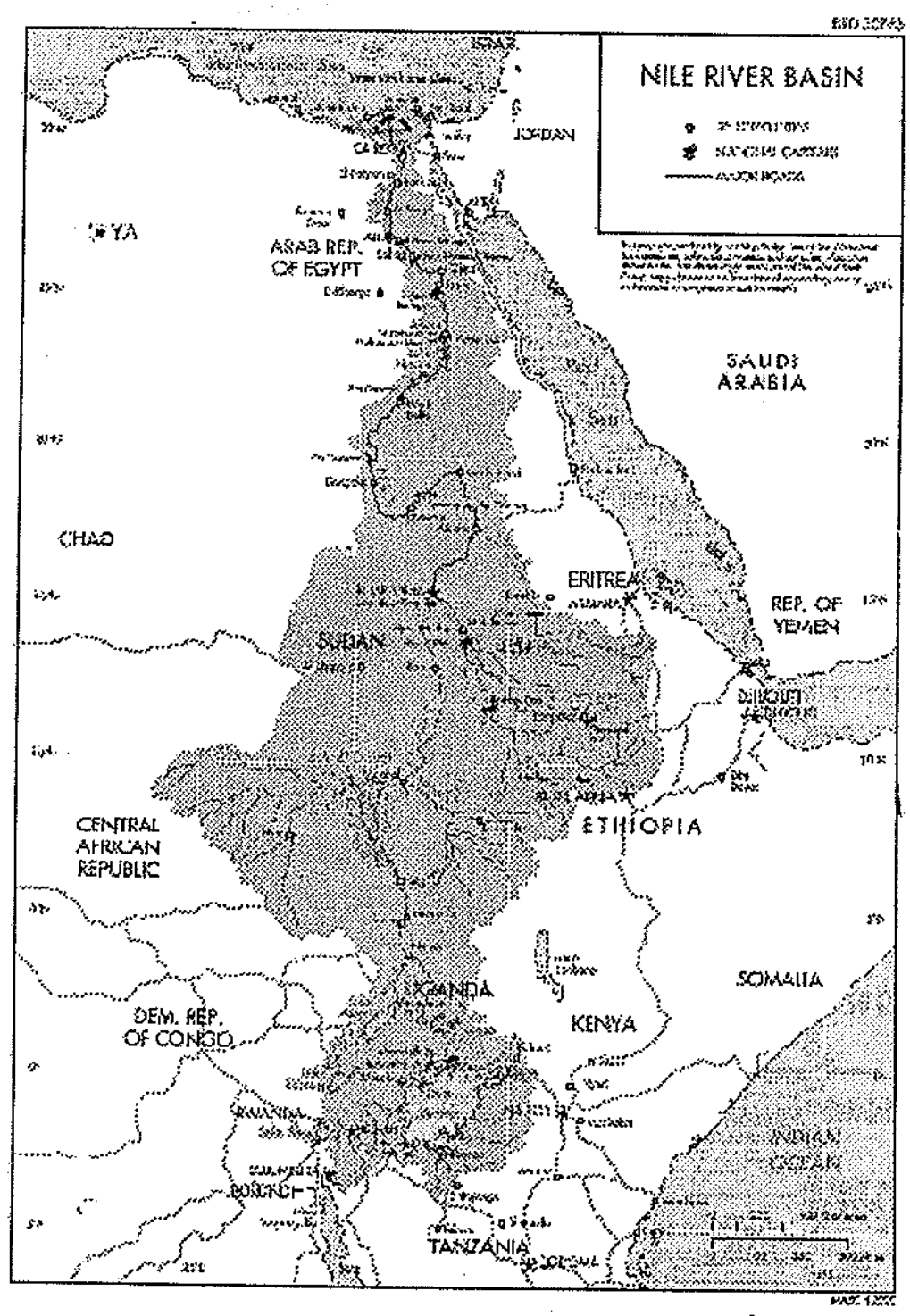

Fig. 1: Map of Nile River Basin [7]

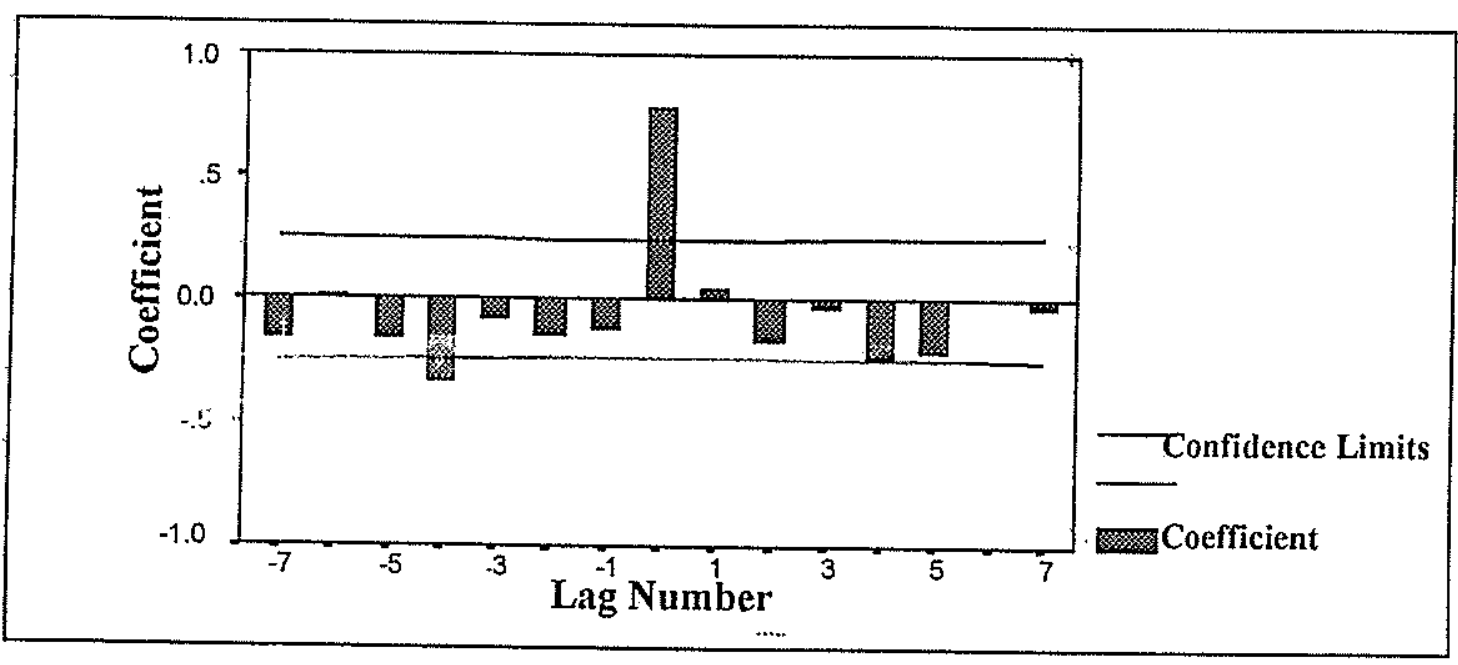

Fig. 2: CCD Between Khartoum and Aswan 


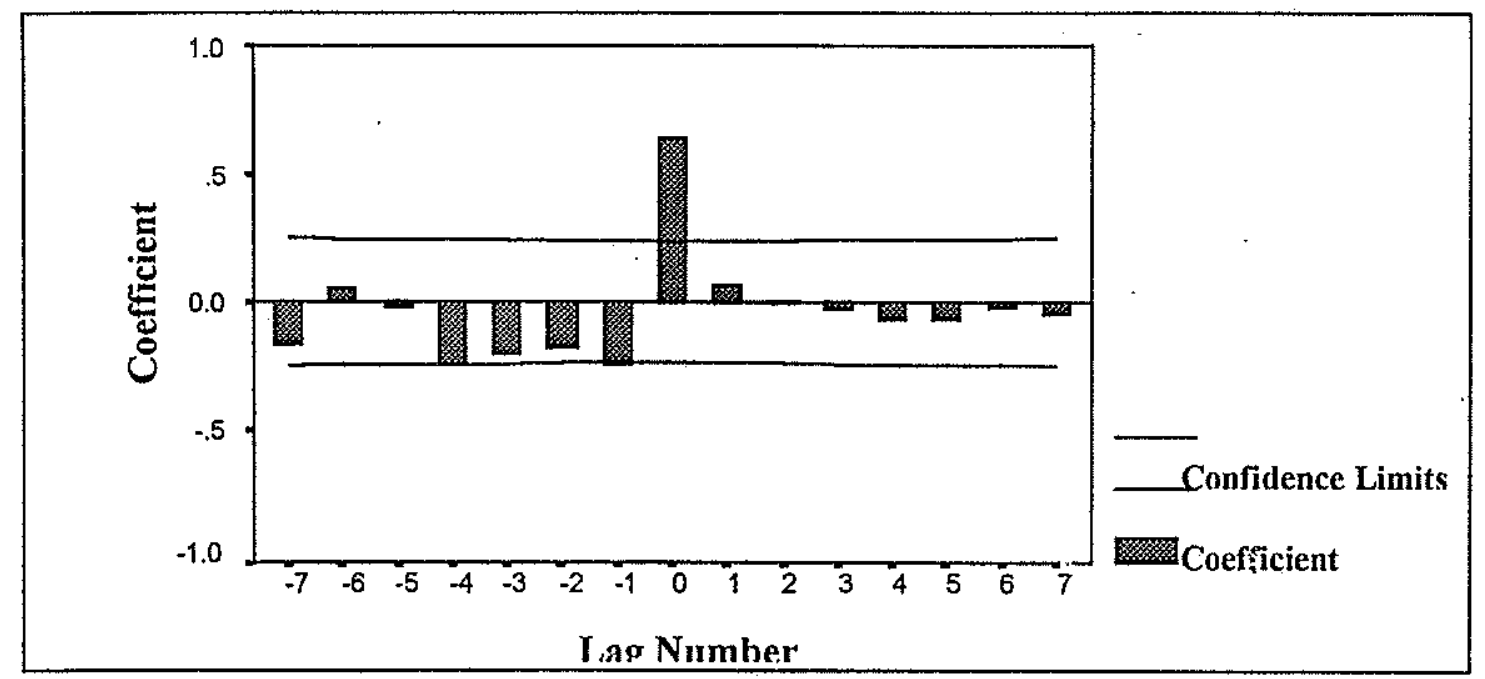

Fig. 3: CCD Between Atbara and Aswan

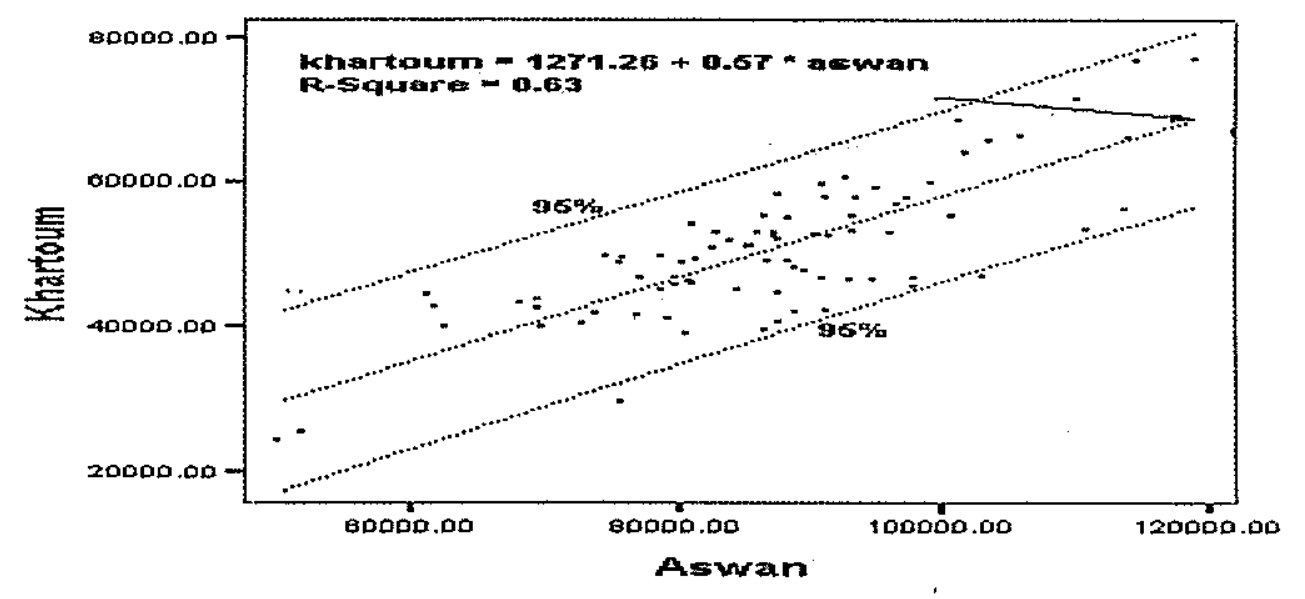

Fig. 4: Contribution of the Blue Nile at Khartoum to the Main Nile at Aswan

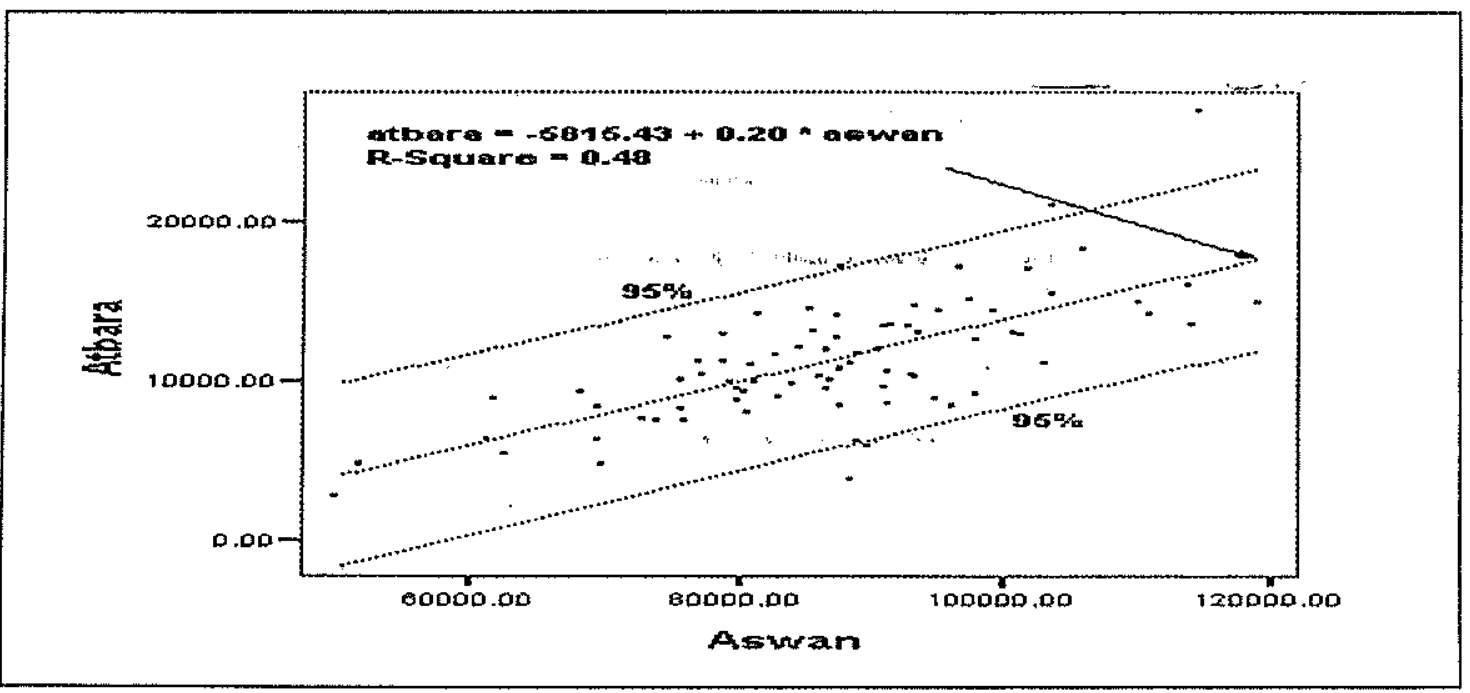

Fig. 5: Contribution of the River Atbara to the Main Nile at Aswan 


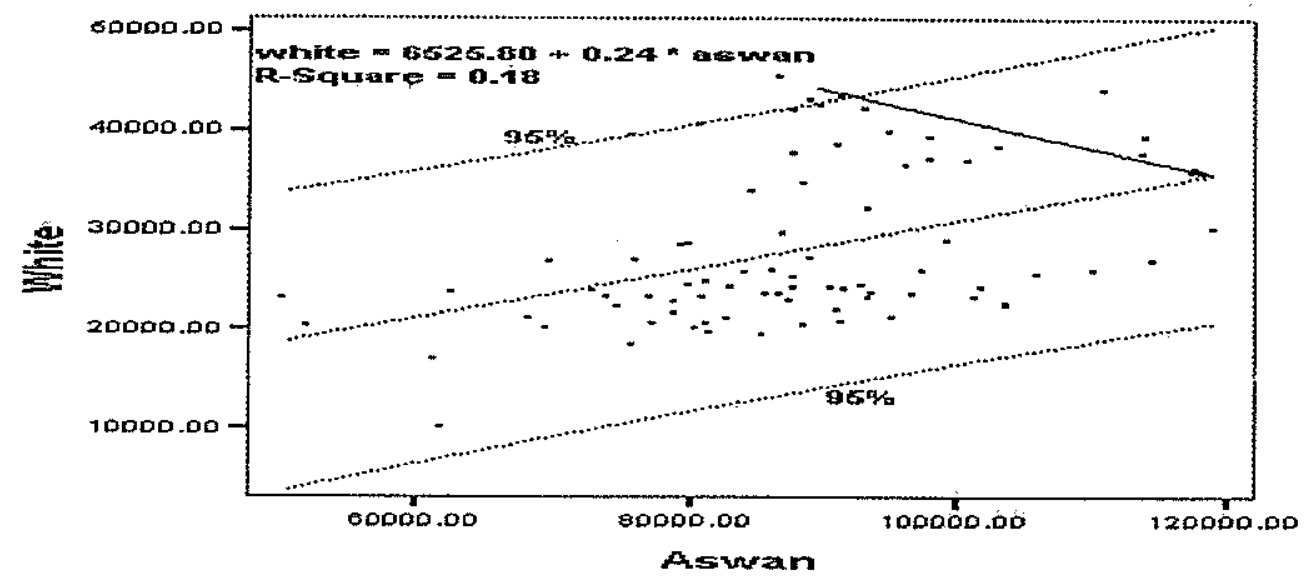

Fig. 6: Contribution of Both the Sobat and the White Nile to the Main Nile at Aswan

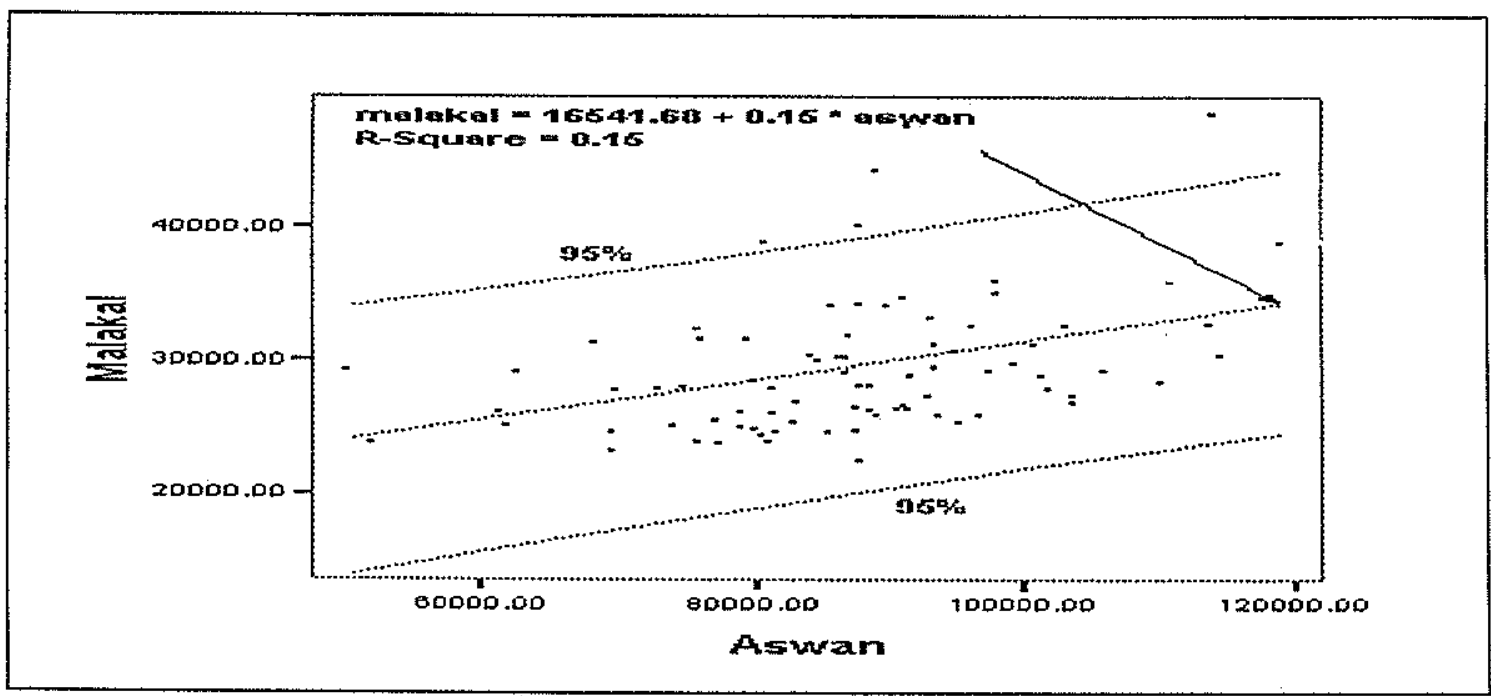

Fig. 7: Contribution of the White Nile at Malakal to the Main Nile at Aswan

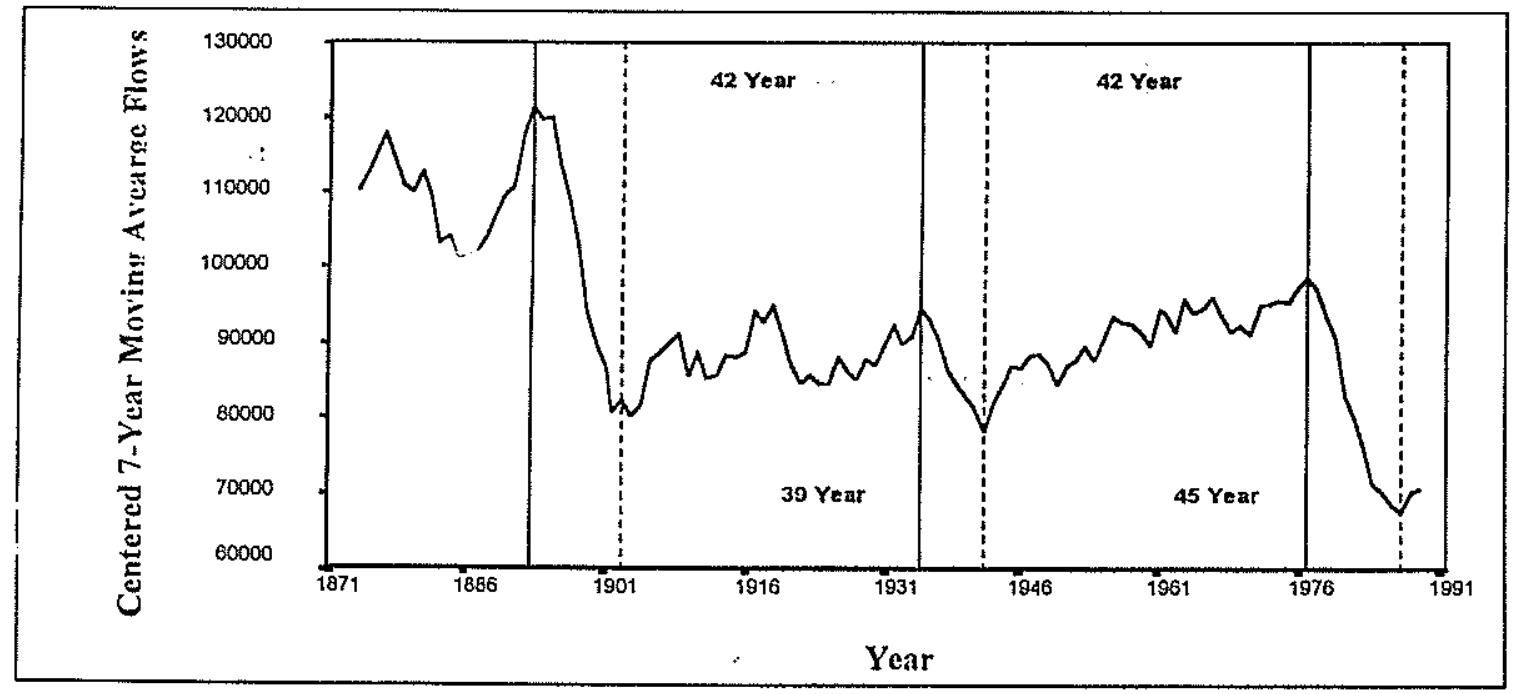

Fig. 8: Seven-Year Moving Annual Flows of the Main Nile at Aswan 
long-term fluctuations and trends in the Nile flow data may be obtained. Looking at the Main Nile flow data in terms of sevenyear moving averages, the average period of peak points is 42 years and that for points of minimum flows is also $(39+45) / 2$ $=42$ years. This indicates that the annual flows of the Nile River at Aswan show a long distinct maximum and a long distinct minimum flow every about 42 years.

Figure 9 shows the smoothed values of the annual flows at Aswan using the double 3-year MA in which short-term fluctuations are significant. As shown from Fig. 9, the average period of peak points is $(17+14+8+7+12+12+9+11+8) / 9=10.9$ and that for points of minimum flows is also $(18+8+7+10+11+11+10+10+13) / 9=10.9$ years. This means that the annual flows of the Nile River at Aswan show a short-term fluctuation of average cycle of about 11 years, a period close the 11 year cycle of sunspot number mentioned earlier by Helmy, A., 1990 [1].

The deviations from the mean annual flow of the Main Nile at Aswan for the period 1871-2001 are plotted as shown in Fig. 10. With the exception of 1913 low flow; most of the lowest flows in the Main Nile at Aswan have been recorded since 1984. In addition, with the exception of years 1981, 1998, 1999 the flows of the Main Nile at Aswan have been below the long mean average since 1979. Thus it is very clear that the flows of the Main Nile at Aswan in the period from 1979 to 2001 have been below normal and that this period encompasses most of the lowest flows ever recorded in the Nile River.

\section{Modeling the Smoothed Series:}

The scope of the present paper is mainly to describe the application of the ARMA model technique to the smoothed annual natural flows of the Nile River instead of the original annual series; therefore only a brief description of the ARMA model will be provided while those interested should refer to the literature available.
ARMA Model Approach:

The ARMA model approach has been widely used since the work of BoxJenkins, 1976 [2]. It is based on the use of autoregressive moving-average parameters for describing and predicting time series. The general notation for ARMA $(p, q)$ model is:

$\phi_{\mathrm{p}}(\mathbf{B}) \mathbf{Y}_{\mathrm{t}}=\theta_{\mathrm{q}}(\mathbf{B}) \cdot \in_{\mathrm{t}}$

In which,

$\mathbf{B}=$ Back shift operator, such that

$$
\text { B } Y_{t}=Y_{t-1} \text {, }
$$

$Y_{t}=$ The value of the predicted series at time $\mathbf{t}$,

$\phi_{\mathrm{p}}=1-\phi_{1} \mathrm{~B}-\phi_{2} \mathrm{~B}^{2}-\phi_{3} \mathrm{~B}^{3}-\ldots \ldots \phi_{\mathrm{P}} \mathrm{B}^{\mathrm{P}}$,

$\theta_{\mathrm{q}}=1-\theta_{1} \mathbf{B}-\theta_{2} \mathbf{B}^{2}-\theta_{3} \mathbf{B}^{3}-\ldots \ldots . \theta_{q} \mathbf{B}^{q}$,

$\epsilon_{\mathrm{t}}=$ Box-Jenkins notation for a purely random process with mean 0 and variance $\sigma^{2}[2]$.

\section{Application and Analysis of Results:}

The available annual natural flows at Aswan include the period 1871-2001 on calendar year basis. The period 1871-1992 is taken as a historical period of the model and that for the period 1993-2001 as a validation period.

\section{Historical Period:}

Computing double 3-year centered moving averages smooths the annual flows at Aswan as shown in Fig. 9. The smoothed series are then examined and found adequately modeled by an ARMA of six successive autoregressive parameters and only two moving average parameters at the pre specified cycles 11, and 42. The equation of the developed model is:

$\hat{\mathrm{Y}}_{\mathrm{t}}=93420.88+2.063 \mathrm{Y}_{\mathrm{t}-1}-1.315 \mathrm{Y}_{\mathrm{t}-2}$

$-0.551 Y_{t-3}+1.471 Y_{t-4}-0.902 Y_{t-5}+$

$0.179 \mathrm{Y}_{\mathrm{t}-6}+\epsilon_{\mathrm{t}}-0.223 \epsilon_{\mathrm{t}-11}-$

$0.212 \epsilon_{\mathrm{t}-42}$

in which,

$\hat{\mathbf{Y}}=\mathrm{Q}-93420.88$,

$\mathbf{Q}=$ Double 3-year MA annual flows, and

$\epsilon_{\mathrm{t}}=$ the error at time $\mathrm{t}=(\mathbf{Y}-\hat{\mathbf{Y}})_{\mathrm{t}}$ 


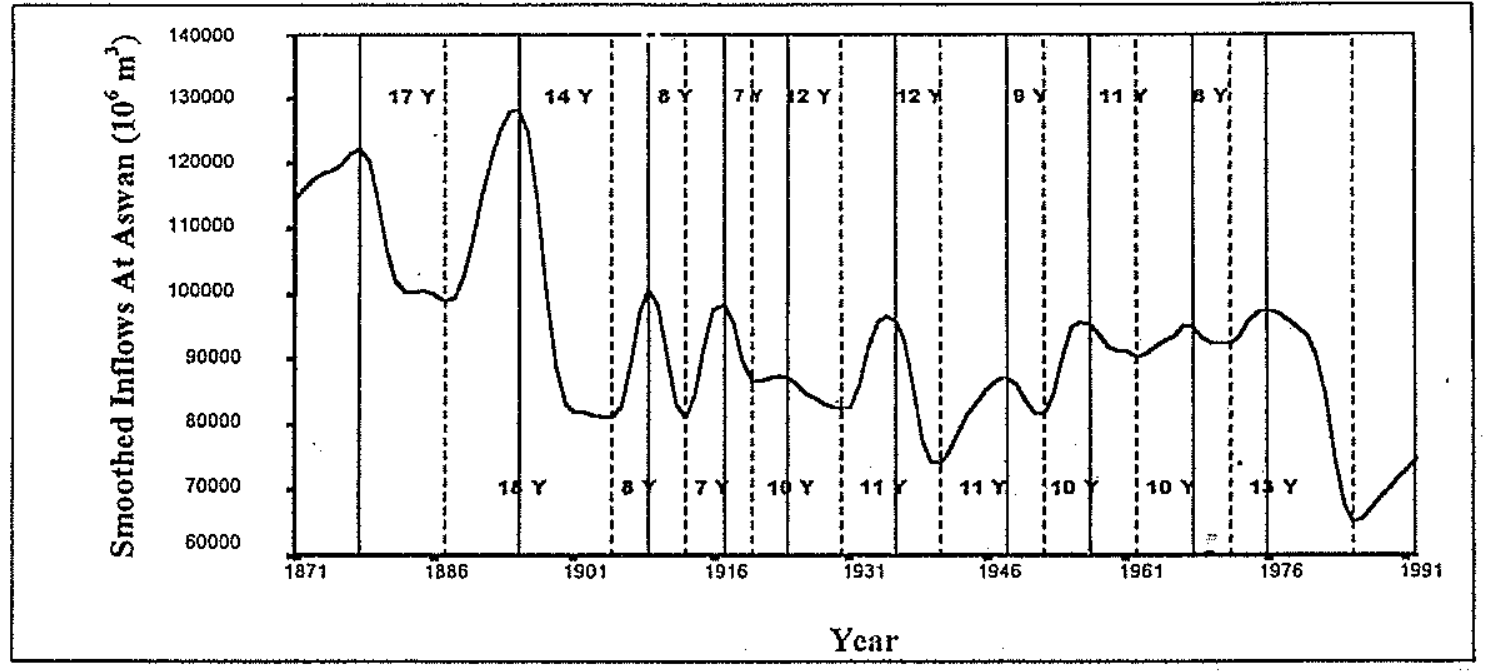

Fig. 9: Double 3-Year Moving Average of the Annual Flows of the Nile River at Aswain

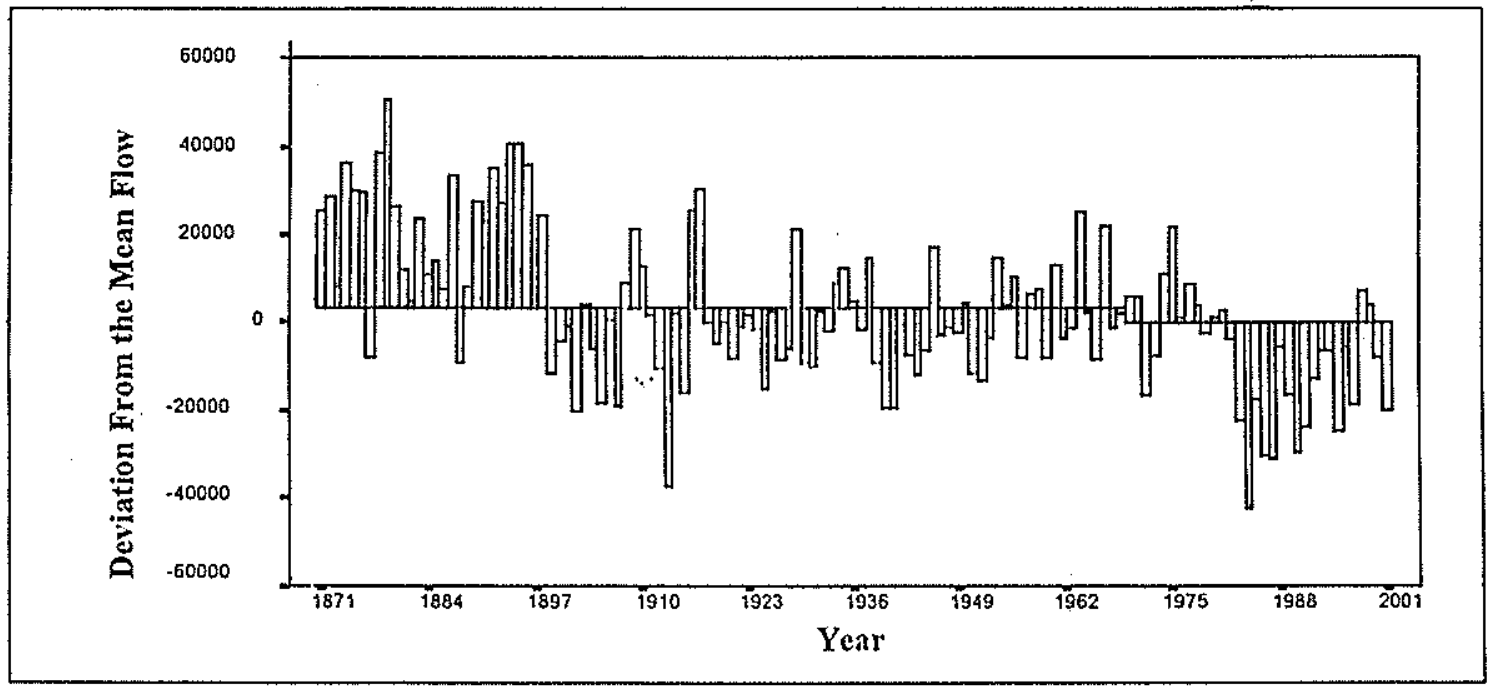

Fig. 10: Deviation From the Mean Flow For the Main Nile at Aswan

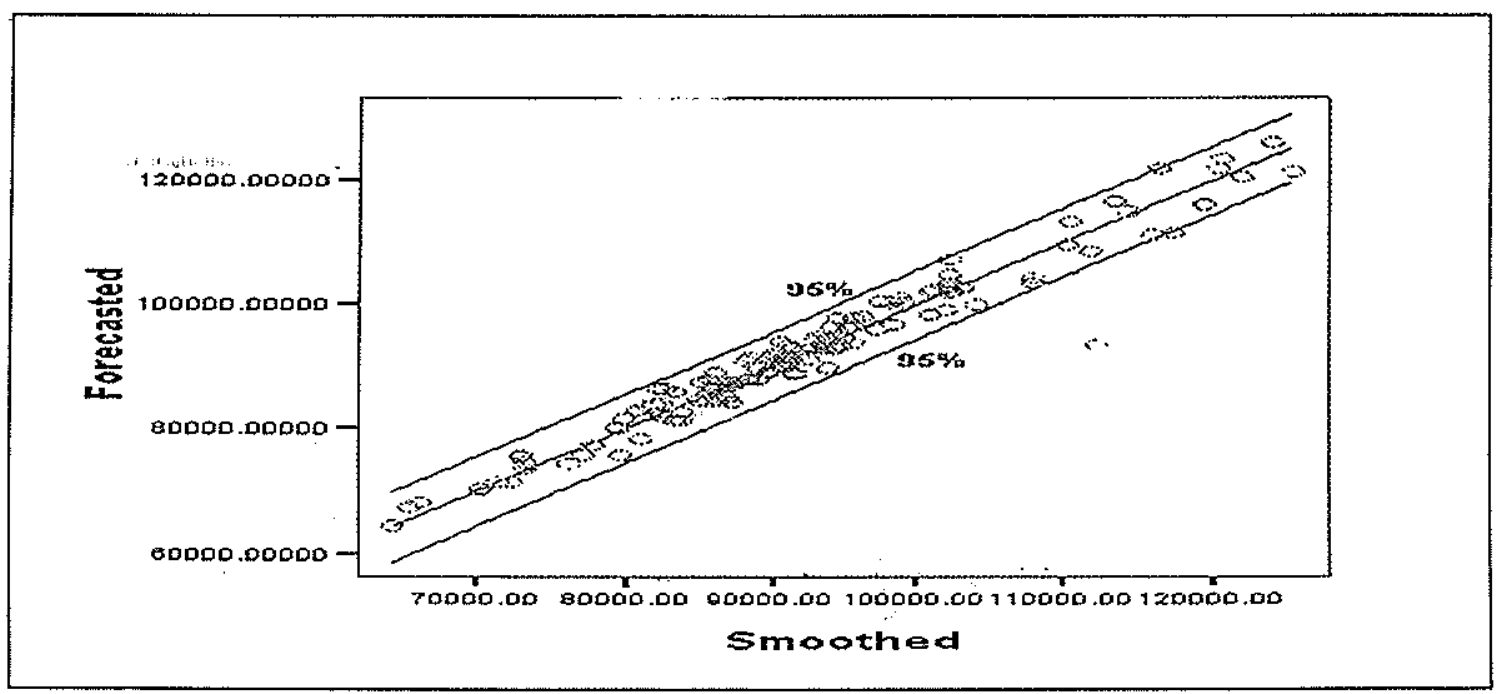

Fig. 11: Forecasted Versus Smoothed Annual Flows At Aswan (Historical Period) 


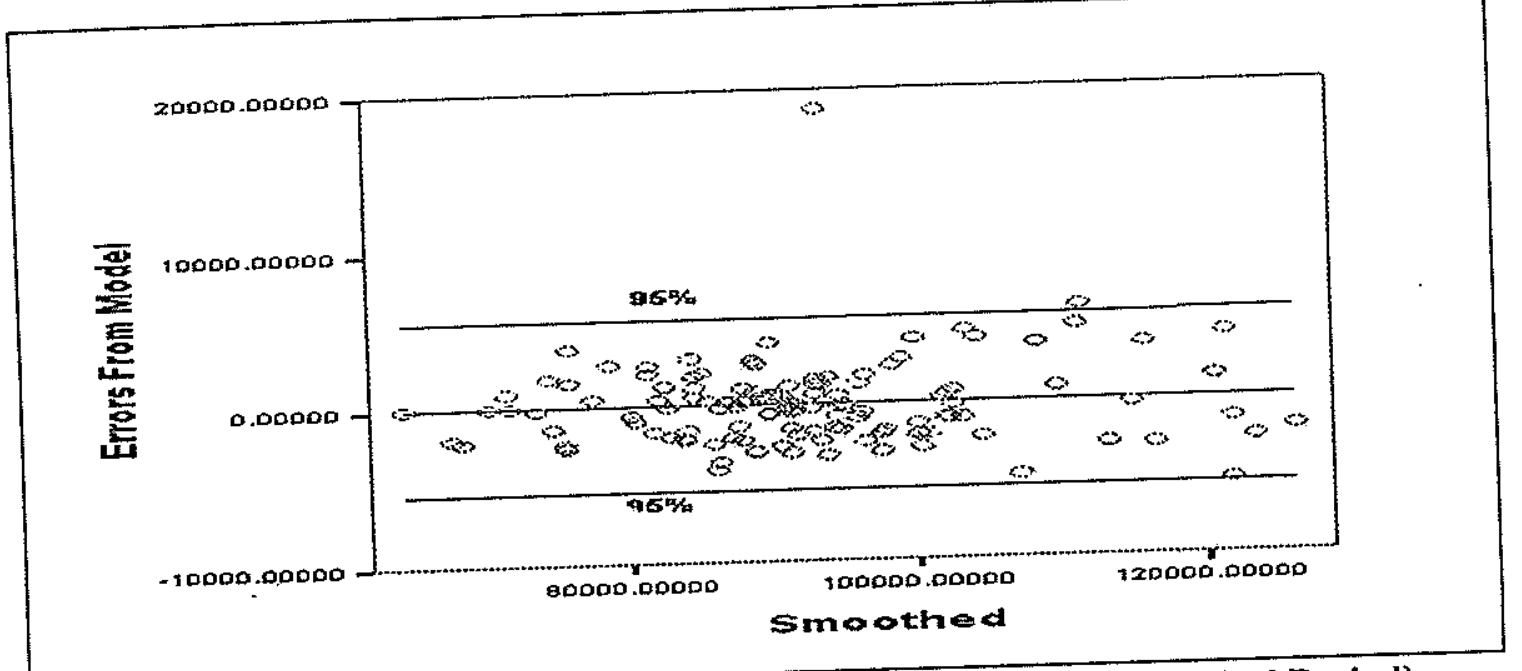

Fig. 12: Errors Versus Smoothed Annual Flows At Aswan (Historical Period)

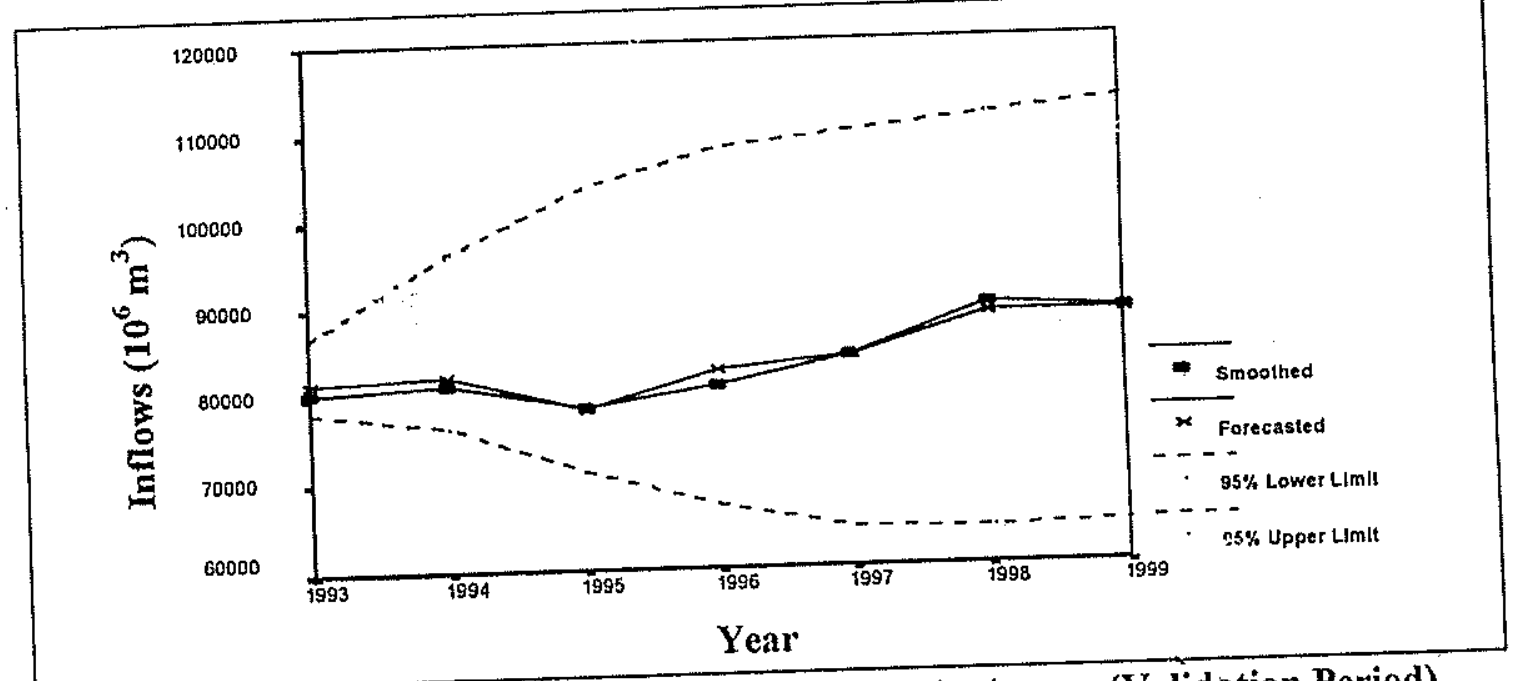

Fig. 13: Forecasted and Smoothed Annual Flows At Aswan (Validation Period)

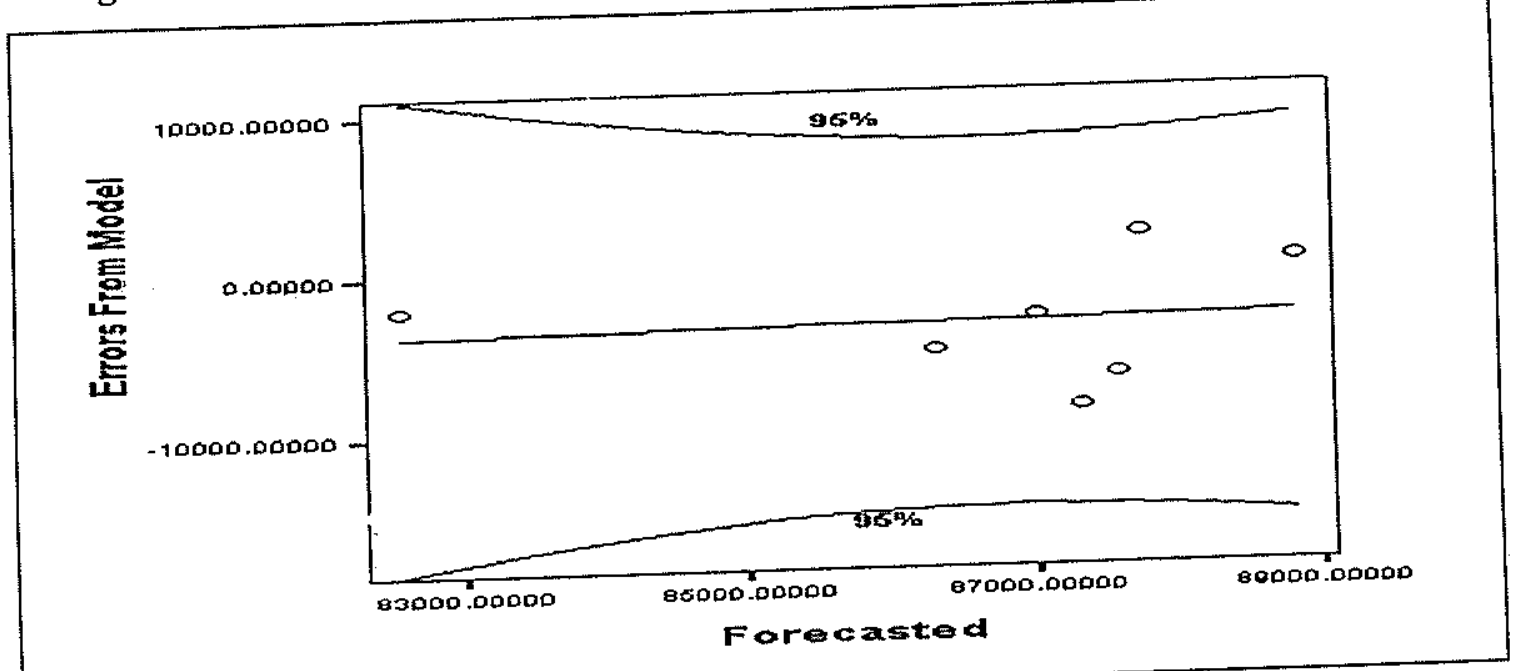

Fig. 14: Errors Versus Smoothed Annual Flows At Aswan (Validation Period) 
To show the validity of such an equation in forecasting the smoothed annual flows at Aswan in the historical period both of the smoothed and error series are plotted against the forecasted values as shown in Figs. 11 and 12 respectively. As shown from Fig. 11, the simulated values are highly correlated with the smoothed values. In contrast, Fig. 12 shows that the errors are uncorrelated with the smoothed series; the errors are white noise, which indicate the adequacy of the developed model.

\section{Validation Period:}

The developed equation is used to forecast future values in the validation period, 1999-2001, the period that does not be used in estimating the model parameters. Figure 13 shows the plot of the smoothed and forecasted series in the validation period, which indicated a great association between the forecasted and smoothed values. Also, the errors left after forecasting the annual flows was plotted versus the forecasted values in the validation period (Fig. 14) seems as a white noise that indicated the adequacy of the developed model in predicting the smoothed series in the validation period as well.

Forecasting Future Values of the Smoothed Series:

After checking the validity of the proposed methodology in forecasting the historical and the validation periods, the total length of the smoothed annial flow records at Aswan, 1871-2001 was used to re-estimate the model parameters. The forecasting equation may take the form:

$\hat{\mathbf{Y}}_{t}=93008.835+2.06 \mathrm{Y}_{\mathrm{t}-1}-1.325 \mathrm{Y}_{\mathrm{t}-2}$

$-0.541 Y_{t-3}+1.506 Y_{t-4}-0.961 Y_{t-5}+$

$0.209 Y_{\mathrm{t}-6}+\epsilon_{\mathrm{t}}-0.247 \epsilon_{\mathrm{t}-11}-$

$0.223 \epsilon_{\mathrm{t}-42}$

Equation 10 is thus used to forecast the future values of the smoothed annual series beyond year 2001, the end of the smoothed seric:
Forecasting the Originai Annual Series at Aswan:

The forecasted values of the smoothed series were then redistributed to obtain the forecasts of the original annual series at Aswan as follows:

$\left(\hat{\mathbf{Y}}_{\mathrm{o}}\right)_{\mathrm{t}}=9 \times \mathbf{P}_{\mathbf{t}} \times \hat{\mathbf{Y}}_{\mathbf{t}}$

in which,

$\left(\hat{\mathbf{Y}}_{\mathrm{o}}\right)_{\mathfrak{t}}=$ Forecasted values of the original

series, and

$\mathbf{P}_{\mathbf{t}} \quad=$ A distribution factor calculated

from $\mathrm{Eq} .12$ as follows:

$P_{t}=Q_{t} /\left(Q_{t-2}+2 Q_{t-1}+3 Q_{t}+2 Q_{t+1}+Q_{t+2}\right)$

$Q_{t}=$ Original annual flows at time $t$.

\section{Diagnostic Checking:}

Figures 15 and 16 show the plot of the autocorrelation diagram (ACD) and the partial autocorrelation diagram (PACD) of the error series $\left(e_{t}\right)$ left after forecasting the original annual series at Aswan. The two figures indicate significant correlations at the first two lags, which indicate the presence of some pattern in errors [2]. Using information from these plots, the errors could be modeled by moving average model of order one. The equation of which lead to:

$$
\hat{\mathbf{e}}_{\mathrm{t}}=0.6637 \mathrm{e}_{\mathrm{t}-1}
$$

In which,

$$
\begin{aligned}
& \mathrm{e}_{\mathrm{t}} \quad=\mathrm{Q}_{\mathrm{t}}-\left(\hat{\mathrm{Y}}_{\mathrm{o}}\right)_{t} \text {, and } \\
& \hat{\mathbf{e}}_{\mathrm{t}}=\text { The forecasted values of the error } \\
& \text { series } \mathrm{e}_{\mathrm{t}} .
\end{aligned}
$$

Figure 17 shows the plot of ACD for the final series and indicated that the errors became a white noise and hence more accurate forecasts were verified. Also, the plot of the final errors versus the final forecasts, Fig. 18, confirmed the obtained results.

The part of the forecasted values obtained from Eq. 13 were added to those obtained from Eq. 11 and the final forecasted values, $(\mathbf{F})_{t}$, were obtained from Eq. 14 as follows: 


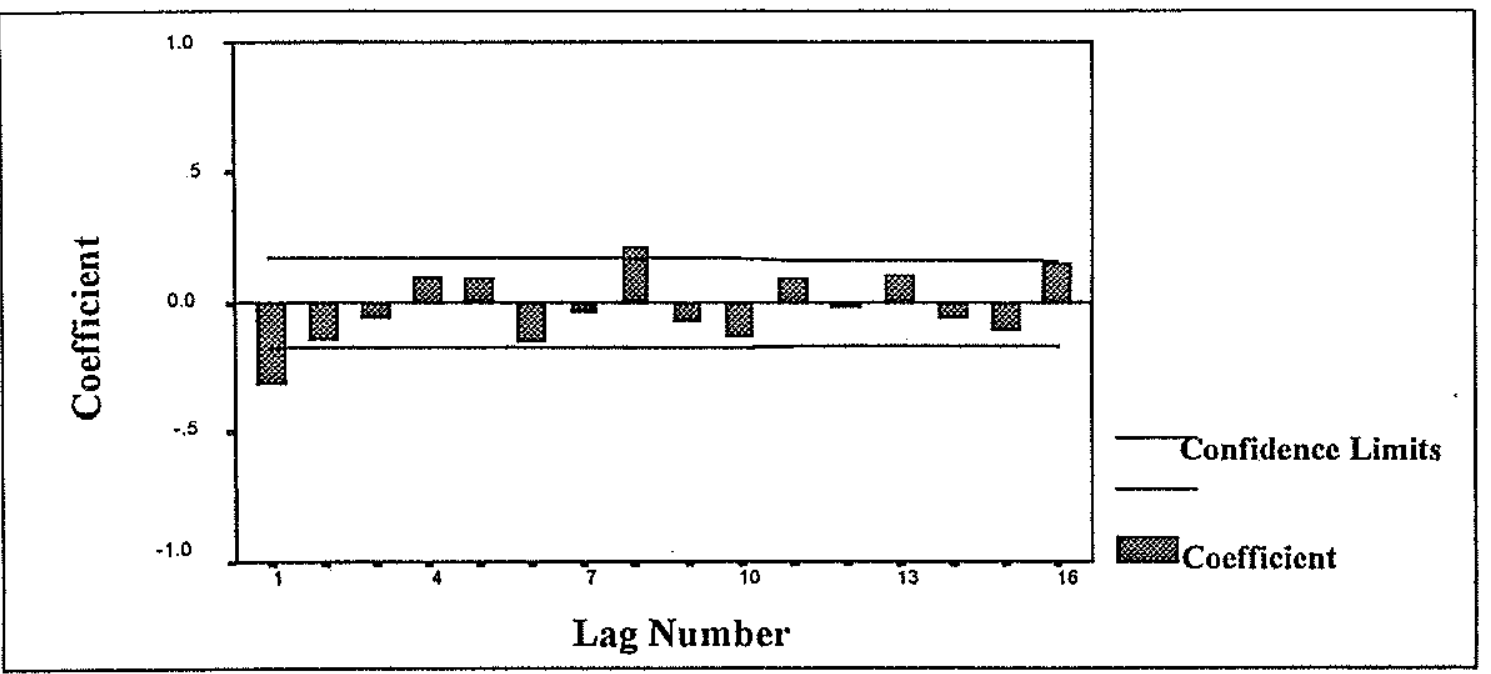

Fig. 15: $A C D$ of the Errors

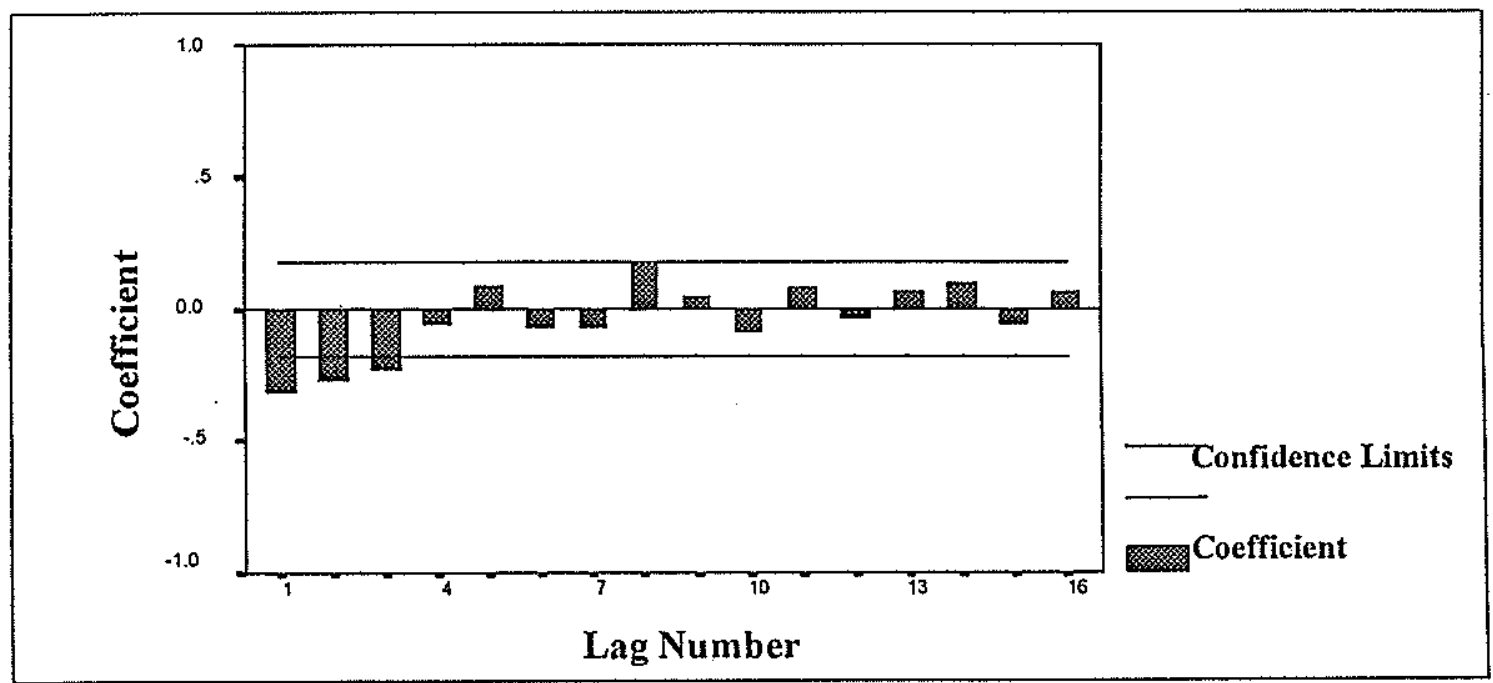

Fig. 16: PACD of the Errors

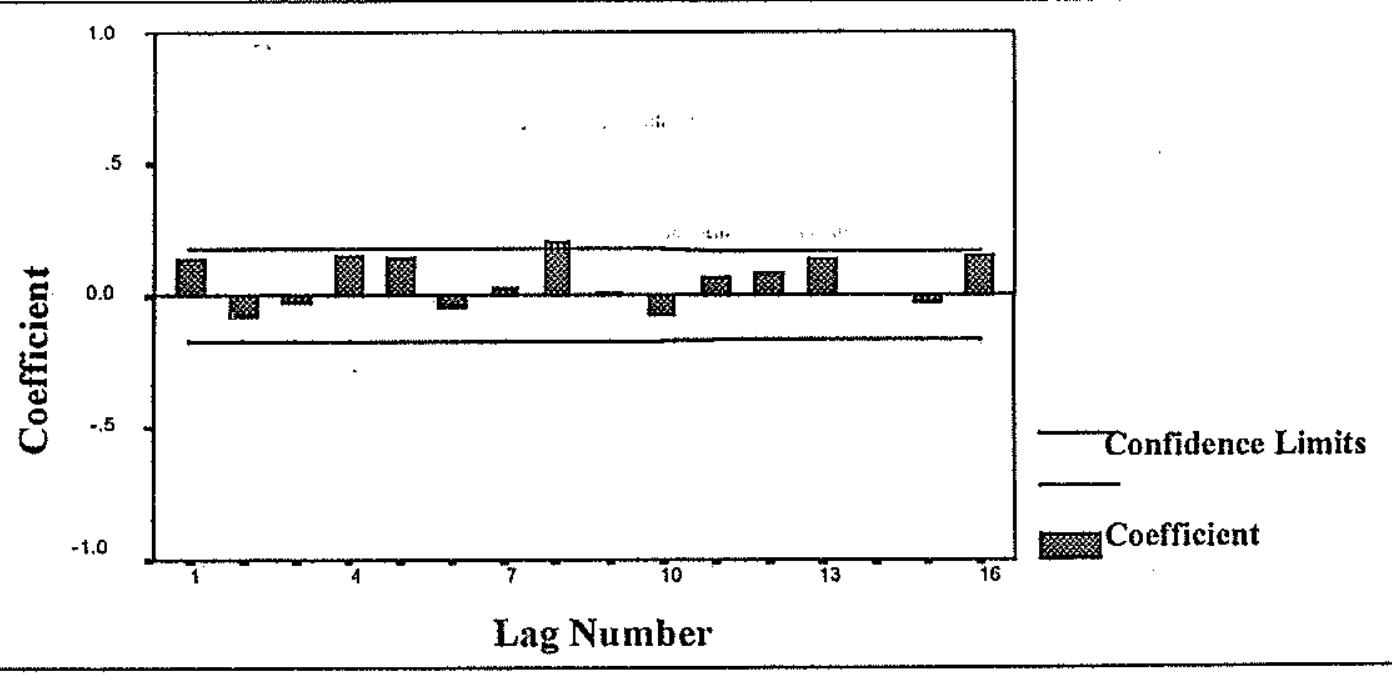

Fig. 17: ACD of the Final Errors 


$$
\text { (F) }=9 \times \mathbf{P} \times \hat{\mathbf{Y}}_{\mathbf{t}}+0.6637 \mathrm{e}_{\mathrm{t}-\mathrm{I}}
$$

The forecasted values were plotted with the original values for the years 18712001 as shown in Fig. 19. The plot in Fig. 19 indicated how the forecasted values followed the original values in both years of floods and years of low flows. This also assured the adequacy of the methodology.

Fig. 20 shows the plot of the forecasted values for the period 2001-20022 along with the $95 \%$ upper and 59\% lower confidence limits. The forecasted values all lie inside the upper and lower limits, which indicate the adequacy of the forecasts obtained and one can rely on them.

For comparison purposes, the original annual series at Aswan were modeled directly using the same ARMA class model and found adequately modeled by an AR(3) model. The forecasting equation of such a model is:

$$
\begin{gathered}
\left(\hat{\mathrm{Y}}_{\mathrm{o}}\right)_{\mathrm{t}}=92816.7+0.37692 \mathrm{Q}_{\mathrm{t}-1}+ \\
0.10642 \mathrm{Q}_{\mathrm{t}-2}+0.20155 \mathrm{Q}_{\mathrm{t}-3}
\end{gathered}
$$

The forecasted values of Aswan obtained using Eq. 15 were compared to those obtained from the smoothed series and both plotted with the original annual flows for the years 1960-2001 as shown in Fig. 21. Based on the plat of Fig. 21, the forecasts obtained using model applied to the original series didn't resemble well the original flows and its accuracy was problematic compared to the forecasts obtained by the applied methodology.

Table 1 presents the statistical properties of the original and forecasted annual flows at Aswan for the period 187.12001, using Eq. 14 and Eq. 15. Based on all statistical properties reported in Table 1, the forecasted values of the original natural flows at Aswan using Eq. 14 describe well the original series than those obtained using Eq. 15 that indicates also the adequacy of the proposed methodology.

Table 2 presents the forecasted values of the natural annual flows at Aswan on calendar year basis up to year 2022. The obtained forecasts were natural flows and must be transformed to measured flows before any decision-making. The first more significant observation from Table 2 and Fig. 20 is the low flow year 2008 and the high flood year 2010 compared to similar low and high flood years at 1995 and 1998 respectively, a cycle of about 12-13 year was found, a period near the pre 11-year cycle obtained from the smoothing process. The second significart observation was that the coming 11-years hopefully bring a mean flow of about $90 \times 10^{9} \mathrm{~m}^{3}$ and about $91 \times 10^{9} \mathrm{~m}^{3}$ in the coming 21-years that give some feel of comfort about the future of the proposed great agriculture development projects in south of the valley and other country regions.

\section{Summary and conclusions}

A brief description of the
Physiography, climate, and hydrology of the Nile Basin was presented. The correlation together with the contribution of each of the four tributaries of the Nile River with the Main Nile at Aswan was examined. The contribution of flow to the Main Nile at Aswan from Ethiopia was found about $86 \%$.

The fluctuations of maximum and minimum flows of the Main Nile at Aswan were studied by smoothing the annual flows at Aswan using moving average technique. It was found that the annual flows of the Nile River at Aswan show a short-term fluctuation of average cycle of about II years and a long-term fluctuation every about 42 years. The annual flows at Aswan are smoothed by double three-year moving ayerage and then modeled by an ARMA model having moving average parameters at the obtained 11 , and 42 lags.

The adequacy of developed model was investigated in both the historical and the validation periods and approved. The model was used to forecast future values of the annual flows at Aswan up to year 2022. A low flow year was expected at year 2008 while, on the other hand, a high flood year was expected at year 2010. A cycle of about 
12-13 year, a period close to the prementioned 11-year cycle, was found between the expected years of low and high floods and the corresponding more recent ones. The mean flow of the coming 11years and 21-years was expected about $90 \times$ $10^{9} \mathrm{~m}^{3}$, and $91 \times 10^{9} \mathrm{~m}^{3}$ respectively that give some feel of comfort about the future of the proposed great agriculture development projects in Egypt.

References:

1. El-Sayed, A. Helmy. "Hydrological Parameters and their Effects on River

Supply". Unpuplished M.SC thesis, Faculty of Engineering, Zagazig University, Egypt, 1990.

2. Box, G.E.P., and Jenkins, G.M. "Time Series Analysis: Forecasting and Control". San Francisco. California, Holden day, 1976.

3. Ethiopian Country Paper. 2000. Ethiopian Country Paper. The 8 th Nile 2002 conference, Addis Ababa, Ethiopia, June 26, 2000.

4. Hussein, A.S.A and EI Daw, A.K. 1989. Evapotranspiratiop in Sudan Gezira irrigation 14 scheme. Journal of Irrigation and Drainage Engineering, American
Society of Civil Engineers, 115(6):10181033.

5. Jovanovic, D. 1985. Ethiopian interests in the division of the Nile waters. Water International, 10(1985)82-85.

6. Makridakis, S., Wheelwright, S.C., and Megee, V.E. " Forecasting: Methods and Applications" $2^{\text {nd }}$ ed. New York, John Wiley and Sons, 1987.

7. NBI. 2000. Nile Basin Initiative. http://www.nilebasin.org/IntroNR.htm

8. Shahin, M. 1985. "Hydrology of the Nile Basin". Elsevier Science Publishing Co., New York, 9. 1985.

9. Shahin, M. 1986. Discussion of the paper entitled "Ethiopian Interests in the division of the Nile Waters", Water International, 21(1)16-22.

10. Owais, T.M. and El-Sayed, A. Helmy. "Impacts of the Nile River Reservoirs System on its Natural Flows: IReview, and Calculating Natural Flow at Aswan". Accepted for presentation in the $2^{\text {nd }}$ Minia International Conference for Advanced Trends in Engineering (MICATE'2002), 7-9 April, Minia, Egypt, 2002.

Table 1: Statistical Properties of the Forecasted and Original Annual Flows at Aswan (1871-2001)

\begin{tabular}{|l|c|c|c|c|c|c|}
\hline & Minimum & Maximum & Mean & Std. Dev. & Skew ness & Kurtosis \\
\hline Original Annual Flows & 50033.3 & 139511.00 & 91800.2 & 16758.6 & .351 & .139 \\
Fitted Using Eq.14 & 51971.0 & 144351.70 & 92166.2 & 16084.4 & .386 & .425 \\
Fitted Using Eq.15 & 71090.1 & 115524.0 & 92302.8 & 9320.58 & .403 & .099 \\
\hline
\end{tabular}

Table 2: Forecasted Annual Natural Flows at Aswan Using Eq. 14

\begin{tabular}{|c|c|c|c|c|c|c|c|}
\hline Year & $\begin{array}{c}\text { Forecasted } \\
\text { Flow } \\
10^{6} \mathrm{~m}^{3}\end{array}$ & Year & $\begin{array}{c}\text { Forecasted } \\
\text { Flow } \\
10^{6} \mathrm{~m}^{3}\end{array}$ & Year & $\begin{array}{c}\text { Forecasted } \\
\text { Flow } \\
10^{6} \mathrm{~m}^{3}\end{array}$ & Year & $\begin{array}{c}\text { Forecasted } \\
\text { Flow } \\
10^{6} \mathrm{~m}^{3}\end{array}$ \\
\hline 2002 & 83455.34 & 2008 & 77865.12 & 2014 & 90691.33 & 2020 & 92201.41 \\
\hline 2003 & 78480.94 & 2009 & 90993.63 & 2015 & 91504.68 & 2021 & 91461.59 \\
\hline 2004 & 90701.15 & 2010 & 103591.9 & 2016 & 90821.04 & 2022 & 92979.19 \\
\hline 2005 & 95401.15 & 2011 & 92878.10 & 2017 & 97175.17 & & \\
\hline 2006 & 96380.63 & 2012 & 90860.99 & 2018 & 96902.35 & & \\
\hline 2007 & 93174.12 & 2013 & 88367.59 & 2019 & 90470.60 & & \\
\hline
\end{tabular}




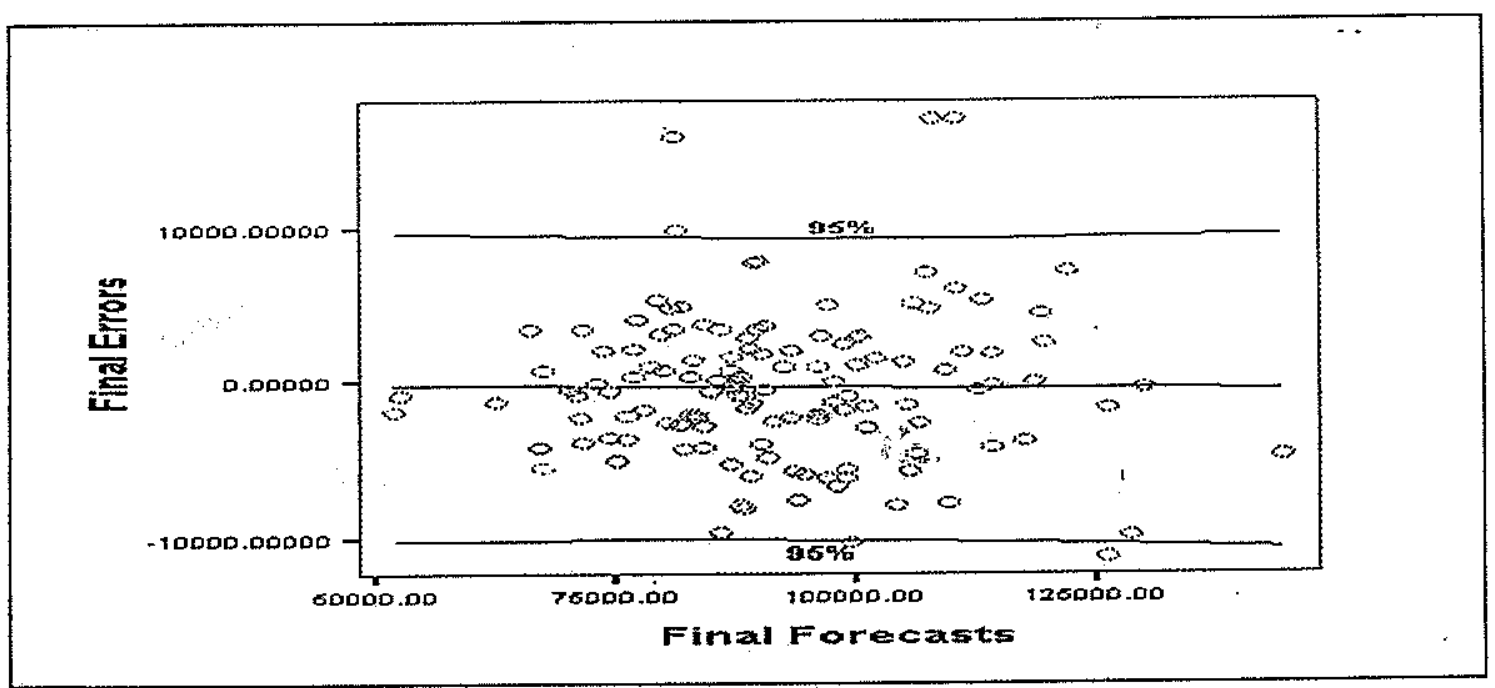

Fig. 18: Final Errors Versus Final Forecasts

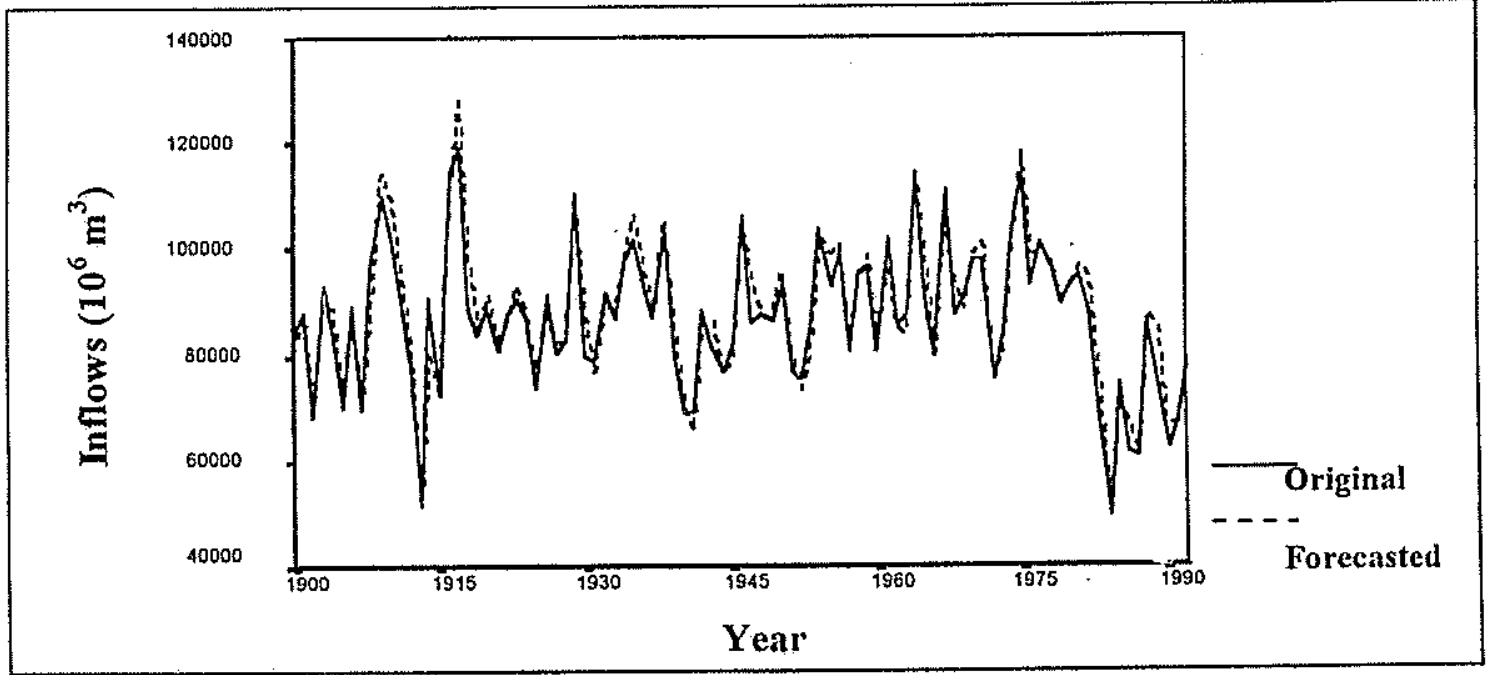

Fig. 19: Forecasted and Original Annual Flows At Aswan

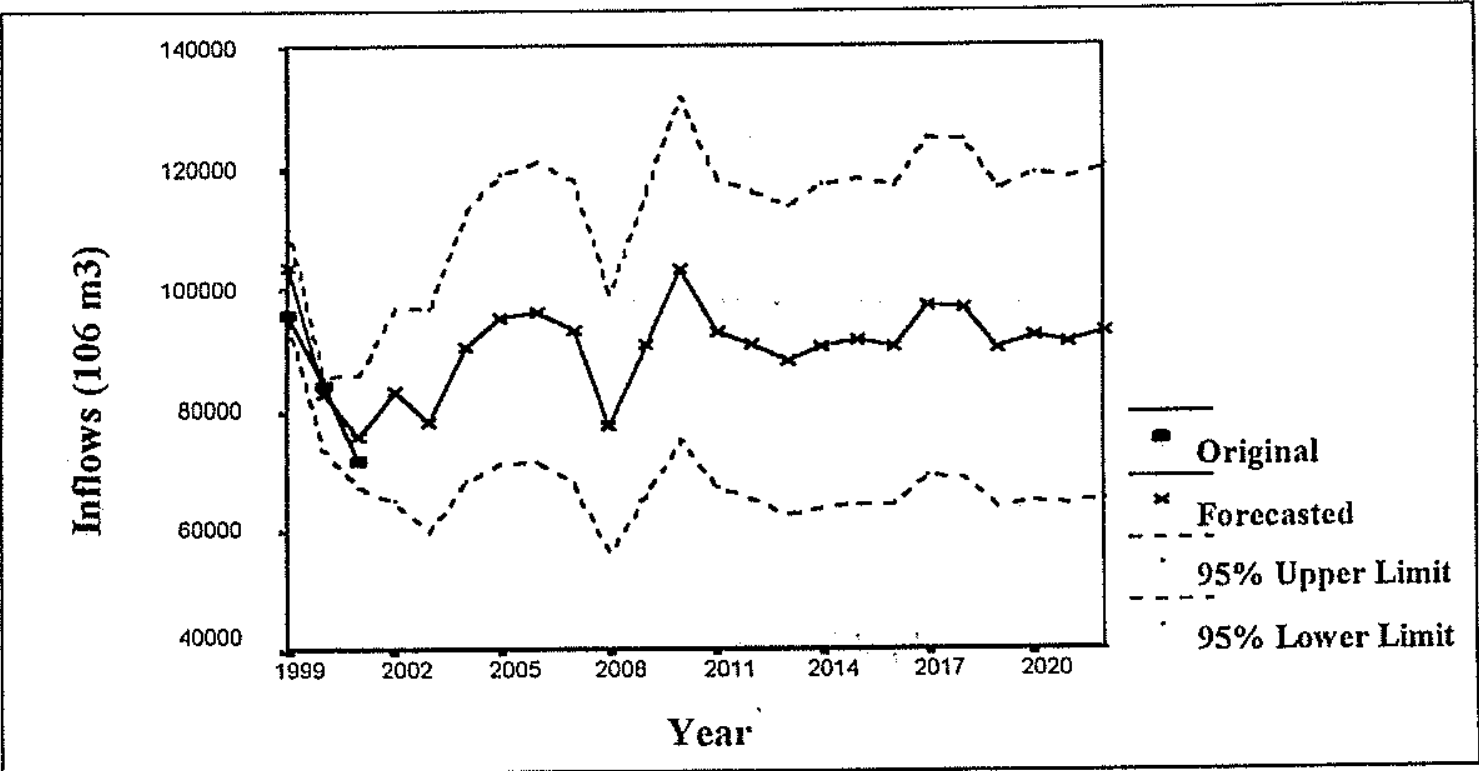

Fig. 20: Forecasted and Original Values of Annual Flows at Aswan (1999-2022) 


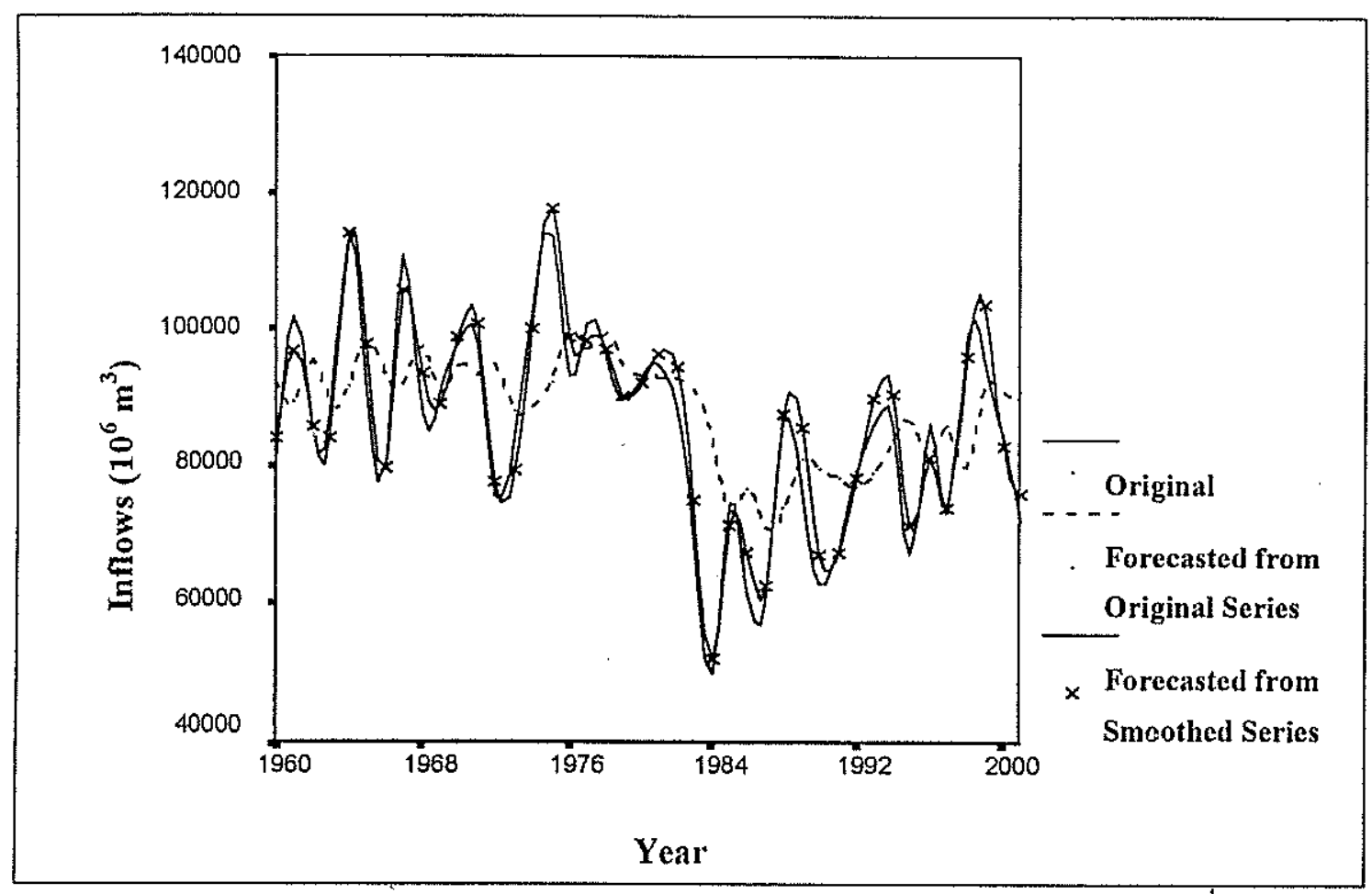

Fig. 21: Comparison of Original and Forecasted Annual Flows of the Nile River at Aswan Using Models Applied to Both the Smoothed and Original Flows 